\title{
ROLE OF COURT OF JUSTICE OF THE EUROPEAN UNION IN ESTABLISHMENT OF EU STANDARDS ON INDEPENDENCE OF JUDICIARY
}

\author{
Marina Matić Bošković, PhD, Research Fellow \\ Institute for Criminological and Sociological Research \\ Gračanička 18, Belgrade, Serbia \\ m.m.boskovic@roldevelopmentlab.com
}

\begin{abstract}
Although the rule of law is globally and regionally increasingly in focus, there are various attempts to blur the separation of powers and weaken judiciary, its integrity and independence through institutional reforms and in individual cases. Judicial independence and integrity are under threat in several EU member states, including Hungary, Romania, and Poland. Judicial crises in the EU jeopardize essential principle of mutual recognition in judicial matters and free movement of goods, services, people and capital. The recent decision of the Irish high judge to refuse to extradite a suspected drugs trafficker to Poland due to concerns about the integrity of the Polish justice system, re-confirms the relevance of the rule of law for the EU and judgement of Court of Justice of EU (CJEU) in case LM, C216/18 PPU. Following Court of Justice decisions related to the Polish judiciary are relevant for shaping Court of Justice position on independence and impartiality of judiciary (i.e. judgment of 24 June 2019, Commission v Poland, C619/18; judgement of 19 November 2019, joined cases A.K. and Others v Krajowa Rada Sadownictwa, C585/18, C624/18 and C625/18).

Backsliding on rule of law in the EU is a possibility that the Court of Justice of the European Union is seeking to prevent and mitigate. In doing so, the Court of Justice is establishing EU standards on independence and accountability of judiciary. There have also been signs that citizens care about the rule of law, highlighting he importance of demand-side initiatives that foster citizen voice. In all, in the current European environment, the rule of law is highly visible and increasingly relevant for citizens, businesses, governments, and EU institutions, especially EU Court of Justice.

In the article author is reviewing Court of Justice decisions relevant for the independence of judiciary, its influence on national legislators, European Commission policy towards access countries and strengthening requests for genuine reform of justice in candidate countries. Consequently, author emphasized the advantages of active role of Court of Justice in establishment
\end{abstract}


of $E U$ standards on independence and impartiality of judiciary in order to prevent further erosion of rule of law, separation of powers and position of judiciary in the member states.

Keywords: Court of Justice, EU standards on independence of judiciary, rule of law, separation of powers

\section{INTRODUCTION}

The rule of law is at the core of the EU system and specifically mentioned in the Article 2 of the Treaty of European Union as the value on which the EU is founded. The rule of law requires the respect of legality, the equality of citizens, the legal certainty, the independence of the judiciary, the accountability of the decision-makers and the protection of human rights. ${ }^{1}$ The rule of law is incorporated in the EU founding treaties and case law of the Court of Justice of the EU (CJEU).

Although the EU is supranational organization founded on common values, it includes Member States with different traditions, some of them with an established rule of law tradition as well as states where the rule of law is relatively new. The EU has to remain cautious with regard to abuses of the rule of law. ${ }^{2}$ The European Commission, together with all other EU institutions is responsible under the Treaties for guaranteeing the respect of the rule of law as a fundamental value of Union and making sure that EU law, values and principles are respected.

The rule of law is not only a common value, but also the foundation of the European integration process. Since 1993 the rule of law has been part of the Copenhagen accession criteria used for assessing the eligibility of the candidate country to join the European Union. The rule of law negotiation chapters, chapter 23 and 24 of the acquis, are at the heart of the European accession process. European Commission expects of candidate countries to fully comply with EU principles relating to the Rule of Law, Judiciary, Fundamental Rights and the Anti-Corruption. Areas of focus of Chapter 23 of accession negotiations are improving judicial independence, both conceptually and functionally, and strengthening impartiality, accountability, professionalism and efficiency of judiciary. Judicial independ-

According to the European Commission the Rule of Law can be defined as "legality, which implies a transparent, accountable, democratic and pluralistic process for enacting laws; legal certainty; prohibition of arbitrariness of the executive powers; independent and impartial courts; effective judicial review including respect for fundamental rights; and equality before the law". European Commission, Communication: A New EU Framework to Strengthen the Rule of Law, COM (2014) 158 Final, pp. 4

2 Sledzinska-Simon, A.; Bard, P., The Teleos and the Anatomy of the Rule of Law in EU Infringement Procedures, Hague Journal on the Rule of Law, 2019, vol. 11, no. 2-3, pp. 440 
ence is crucial since national courts need to apply EU acquis and uphold rule of law within the EU. ${ }^{3}$

The phenomenon of rule of law backsliding ${ }^{4}$ raised attention after judicial reforms in Hungary ${ }^{5}$ and Poland ${ }^{6}$ where Governments have sought to reduce judicial independence and jeopardize checks and balances by limiting the power of their respective constitutional courts. The EU has political and legal mechanisms to address challenges with rule of law in the Member States. The political mechanism is incorporated in the Article 7 of the TEU, while legal action may take form of infringement proceeding in line with Article 258 TFEU.

Since 2015, the Polish authorities have enacted a series of judicial reforms including the creation of new disciplinary procedures and oversight body for judges that have dramatically increased political oversight of the judiciary. Already in 2016 the European Commission triggered mechanism under the EU Framework to strengthen the Rule of Law to prevent further negative influence on rule of law in Poland and adopted $1^{\text {st }}$ Rule of law recommendation 2016/1374. ${ }^{7}$ In addition, judgement of the Court of Justice of the EU in Case $L M^{8}$ regarding the decision of the Irish high judge to refuse to extradite a suspected drugs trafficker to Poland due to concerns about the integrity of the Polish justice system, re-confirms the relevance of the rule of law for the EU. Same mechanism was triggered against Hungary in 2017 for concerns about the functioning of the country's institutions, including problems with the electoral systems, independence of the judiciary and

3 Lenaerts, K., New Horizons for the Rule of Law Within the EU, German Law Journal, 2020, vol. 21, no. 1, pp. 30

4 Pech, L.; Scheppele, K.L., Illiberalism Within: Rule of Law Backsliding in the EU, Cambridge Yearbook of European Legal Studies, 2017, vol. 19, pp. 8

5 The independence of the judiciary has been jeopardized since right wing government gain power in 2010. By introducing new age limits for retirement with immediate effect, 27 percent of Supreme Court judges and more majority of appeal court presidents were removed, and the positions were filled by lawyers loyal to the government. Bard, P., EU responses to rule of law backsliding in the Member States - the Hungarian case, 2017, Hungarian Europe Society, Budapest, available at: [https://europatarsasag. $\mathrm{hu} /$ sites/default/files/open-space/documents/magyarorszagi-europa-tarsasag-rolmet.pdf], Accessed 31. March 2020

6 Since gaining power in 2015, the Polish right-wing government has used the populist blueprint to radically reform the justice system. Bugarič, B., Central Europe's descent into autocracy: A constitutional analysis of authoritarian populism, International Journal of Constitutional Law, vol. 17, no 2, 2019, pp. 597-616

7 Commission Recommendation (EU) 2018/103 of 20 December 2017 Regarding the Rule of Law in Poland Complementary to Recommendations (EU) 2016/1374, (EU) 2017/146 and (EU) 2017/1520, [2017] OJ L17/50, [https://eur-lex.europa.eu/legal-content/EN/TXT/PDF/?uri=CELEX:32018H0103\&from=EN]

$8 \quad$ Case C-216/18 PPU LM, [2018] ECLI:EU:C:2018:586 
the respect for citizens' rights and freedoms. ${ }^{9}$ One of the problems in Hungary was the fact that the competences of the Hungarian Constitutional Court were limited as a result of the constitutional reform, including with regard to a budgetary matters, the abolition of the action popularis and other important issues.

These recent experience with EU member states and challenges in the negotiation process with candidate countries influenced on the content of a New methodology for the accession negotiations that was adopted on February 5, 2020. The application of the methodology depends on rule of law progress in the member states and genuine delivery of reforms in candidate countries to ensure irreversibility of the process. The CJEU decisions shaped EU judicial standards and will provide stronger arguments to the European Commission in the process of European integrations and assessment of progress in judicial reforms. The CJEU jurisprudence is especially relevant in the discussion with candidate countries that are emphasizing the fact that Member States have different judicial systems with no hard standards on organization of judiciary.

\section{EU STANDARDS ON INDEPENDENCE OF JUDICIARY}

The Fall of Berlin Wall in 1990 led to opening of the accession process for former Warsaw Pact member states that had different legal traditions. This accession process that included 12 countries raised issues of European judicial standards. Although the EU member states judiciaries are different from country to country, as well as constitutional regulation of independence and impartiality of judiciary, ${ }^{10}$ the rule of law is accepted as a common value.

For many years judiciary and internal affairs incentivize discussion on their role within the EU acquis, lack of democratic responsibility and human rights protection. ${ }^{11}$ Only for the last decade, after adoption of Lisbon Treaty, the EU got a legal ground to act in the area of criminal law and influence on the judiciary and legislation in the member states in this specific area. ${ }^{12}$

9 European Parliament resolution of 12 September 2018 on a proposal calling on the Council to determine, pursuant to Article 7(1) of the Treaty on European Union, the existence of a clear risk of a serious breach by Hungary of the values on which the Union is founded, 2017/2131(INL)

10 More about differences among Member States judicial systems: Gutmann, J.; Voigt, S., Judicial Independence in the EU - A Puzzle, ILE Working Paper Series, No. 4, 2017, [https://www.econstor.eu/ bitstream/10419/156756/1/ile-wp-2017-4.pdf], Accessed 08. April 2020

11 Peers, S., Justice and Home Affairs Law since the Treaty of Lisbon: A Fairy-Tale Ending?, in: Arcarazo, D. A.; Murphy, C. C. (eds.), EU Security and Justice Law after Lisbon and Stockholm, Hart Publishing, 2014, pp. 17

12 Craig, P., The Lisbon Treaty - Law, Politics, and Treaty Reform, Oxford University Press 2013, pp. 336 
In the area of the criminal law and judiciary the EU relied on Council of Europe standards. According to the article 6 of the TEU the EU is obliged to respect fundamental rights guaranteed in the human rights conventions. In addition, the integral part of the Lisbon Treaty is Protocol 8 relating to the accession of the Union to the European Convention of Human Rights and Fundamental Freedoms. ${ }^{13}$ European Convention of Human Rights and Fundamental Freedoms and European Court of Human Rights (ECtHR) developed human rights standards (right to a fair trial and access to justice) and within them standards on judiciary, before the EU started to intervene in this area. ${ }^{14}$ Although the EU, especially CJEU is developing own judicial standards through the interpretations, the basis represent the Council of Europe rule of law standards and ECtHR jurisprudence. ${ }^{15}$

Although the organization of justice in the Member States falls within the national competences, the Member States are required to comply with their obligations under the EU law. In addition, in accordance with the Article 19(1) TEU the Member States are obliged to ensures that courts and tribunals within the meaning of EU law meet the requirement of the effective legal protection within the denotation of the Charter of Fundamental Rights of the European Union. Courts and tribunals can provide such protection only if sustaining their independence. According to article 47 paragraph 2 the Chapter of fundamental rights of the EU everyone is entitled to a fair and public hearing within a reasonable time by an independent and impartial tribunal previously established by law.

EU standards are defined based on the goals that should be achieved, namely independence, impartiality, integrity, efficiency and trial within the reasonable time, while instruments for their realization are different among the member states. Challenges that Romania and Bulgaria had in the area of judiciary and fight against corruption provided additional incentives for the Council of Europe and European Union to standardize criteria for the measuring the progress of the judicial reforms and achievement of European standards.

13 Defeis, E. F., Human Rights and the European Court of Justice: An Appraisal, Fordham International Law Journal, vol. 31, no. 5, 2007, pp. 1104-1117

14 Škulić, M., Osnovni evropski standardi u krivičnom postupku Srbije, in: Kron, L.; Jugović, A., (eds.), Kriminal, državna reakcija i harmonizacija sa evropskim standardima, Institut za kriminološka i sociološka istraživanja, Beograd, 2013, pp. 29-55; Vervaele, J. A. E., Evropsko kazneno pravo i opća načela prava Unije, Hrvatski ljetopis za kazneno pravo i praksu, vol. 12, no. 2, Zagreb 2005, pp. 855-882

15 Memorandum of Understanding between the Council of Europe and the European Union of May 2007 
International law recognizes link between human rights, specifically right to a fair trial and independence and accountability of judiciary. ${ }^{16}$ Independence of judiciary is based on the right of the individual to a fair trial, so independent judiciary as well as prosecution are crucial elements of the fair trial. Although the accused person has right to a fair trial, it cannot be concluded that judge or a prosecutor have right to be independent. ${ }^{17}$ Right to an independent judiciary is issue of the accountability of judiciary that is incorporated in the legislation ${ }^{18}$ to be independent and impartial in exercising right to a fair trial. Discussion on independence of the judiciary and its elements should be focused on its purpose of guarantying right of each individual to a fair trial.

Council of Europe developed some of the main European judicial standards, which are further evolved within the EU institutions. ${ }^{19}$ European standards that relates to the independence of judiciary include recommendations on procedure for selection of judge's candidates, appointment of judges, irremovability, career path and promotion, accountability, financial independence and tenure. ${ }^{20}$ Furthermore, there is a distinction between external and internal independence. ${ }^{21}$ Judicial councils are recommended as guarantee of independence of judiciary. ${ }^{22}$

Standards of independence of judiciary refer more on courts and judges than prosecution service and public prosecutors. However, over last few years in Europe prevails opinion that independence of prosecution is also important for establishment of independent judicial system, since public prosecutors are a key part of the criminal justice chain. ${ }^{23}$ Public prosecutors decide on criminal prosecution, withdrawal of criminal prosecution, diversion of prosecution, provide legal qualification of the offence, propose criminal sanction, etc. The public prosecutors are

16 See: Bangalore principles of judicial conduct adopted in 2002. Value 1 is independence and it is defined as "a pre-requisite to the rule of law and a fundamental guarantee of a fair trial"

17 Report of the Special Rapporteur on the independence of judges and lawyers - Judicial accountability, 2014, A/HRC/26/32

18 See: OSCE Document of the Copenhagen meeting of the conference on the human dimension of the OSCE from 1990 and Document of the Moscow meeting of the conference on the human dimension of the OSCE from 1991

19 Matić Bošković, M.; Nenadić, S., Evropski standardi u oblasti pravosuđa, Strani pravni život, 2018, vol. 62, no 1, pp. 39-56

20 European Charter on the statute for judges and Explanatory Memorandum, Council of Europe, 1998

21 Recommendation $\mathrm{CM} / \operatorname{Rec}(2010) 12$ of the Committee of Ministers to member states on judges: independence, efficiency and responsibilities

22 Garoupa, N.; Ginsburg, T., Guarding the Guardians: Judicial Councils and Judicial Independence, American Journal of Comparative Law, vol. 57, Oxford University Press 2008, pp. 103-134

23 Matić Bošković, M.; Ilić, G., Javno tužilaštvo u Srbiji: Istorijski razvoj, međunarodni standardi, uporedni model i i zazovi modernog društva, Institut za kriminološka i sociološka istraživanja, Beograd, 2019, pp. 74 
perceived as gatekeepers of the courtroom, since withdrawal of criminal prosecution by the public prosecutor present finalization of the procedure and the judge cannot process case further. ${ }^{24}$

It is of utmost importance that public prosecutors are objective in proceedings and decision making, and to impartially apply criminal law. Independence of the public prosecution is necessary element of the right to a fair trial, however, specific level of the control over the prosecution is needed to ensure that there is no abuse of the competences. Assessment of the independence and impartiality of public prosecutors should include structural independence of public prosecutors and functional independence. Lack of autonomy and functional independence can jeopardize credibility of prosecution and public trust in the justice system. ${ }^{25}$

One of the elements usually discussed within the standards of the independence of the judiciary are judicial councils as body that should guarantee independence. The Resolution of the General Assembly of the European Network of Judicial Councils, adopted in Budapest on 23 March 2008, emphasized that majority of the European countries have judicial councils or similar independent or autonomous institutions, separate from executive and legislative powers, with the competence to protect and guarantee independence of the judiciary. ${ }^{26}$

Independence of the judicial councils should be understood that councils should be protected from undue influence of executive and legislative powers. ${ }^{27}$ Comparative examples show that structural and operational autonomy is necessary as well as clear legal background and competences. Transparent procedure of election of judicial council members, adequate human resource policy and internal controls are needed elements for prevention of influence over the councils' work.

European Network of Judicial Councils in its Report from 2010-2011 stressed that "mechanism of appointment of council's members from the judiciary must exclude any interference of executive and legislative powers and that judiciary members should be elected by their peers". Many authors emphasized relevance of election of the majority of members from the judiciary by their peers, while

24 Tonry, M., Prosecutors and Politics in Comparative Perspective, Crime and Justice, vol. 41, 2012, pp. $1-33$

25 Report of the Special Rapporteur on the independence of judges and lawyers, 18 April 2011, A/ HRC/17/30/Add.3, paras. 16 and 87

26 Resolution of the General Assembly of the European Network of Judicial Councils on Self Governance for the Judiciary: Balancing Independence and Accountability, [http://www.encj.eu/images/stories/ pdf/resolutionbudapestfinal.pdf]. Accessed 06. April 2020

27 Autheman, V., Sandra Elena, S., Global best practices: Judicial Council - Lessons learned from Europe and Latin America, USAID, 2004 
political control over the process of election can influence on the perception of the independence of councils' work. ${ }^{28}$

Members of the judicial council should be elected based on objective criteria in transparent and fair procedure, to avoid politicization and protect independence of judiciary. However, election by the peers or appointment by the Parliament cannot fully prevent external or undue influences on the council. European standards relevant for the judicial councils are listed in the Council of Europe Recommendation and Opinion, ${ }^{29}$ like clear legal framework that regulates competences, position, members election, accountability, human and financial resources, procedure and work processes, etc. Legal framework should be established by the highest legal act in the country (constitution) or by the law. Countries that decided to apply South European model of the council that among other competences elects judges and prosecutors, usually regulate council by the constitution. ${ }^{30}$

The biggest challenge for sustainability of the European judicial standards represent difference between member states legal systems. Formal acceptance of European values in the form of recognition and incorporation of standards in national legislative framework does not guarantee their practical acceptance. Having in mind that listed European judicial standards include values, their application and irreversibility of the reforms depends on acceptance of these values and social principles and standards. This is confirmed in the survey results which show that de jure guarantees of the independence are not in the direct relation with de facto independence. $^{31}$

\section{COURT OF JUSTICE JURISPRUDENCE ON STANDARDS OF INDEPENDENCE OF JUDICIARY}

Member States and their organization of judiciary differ due to historical reasons. These differences are treated as diversity that have not prevented the EU from establishing the European area of freedom, security and justice. Introduction of mutual trust and mutual recognition of judgements, as well as reorganization and reform of judiciary in some countries raised question of violation of rule of law.

28 Guarneri, C., Judicial independence in Europe: threat or resource for democracy?, Representation, Journal of Representative Democracy, 2013, vol. 49, no. 3, pp. 347-359

29 Recommendation $\mathrm{CM} / \operatorname{Rec}(2010) 12$ of the Committee of Ministers to member states on judges: independence, efficiency and responsibilities; Consultative Council of European Judges Opinion No 10 on Council for the Judiciary in the Service for Society, 2007

30 Matić Bošković, M., Tužilački saveti i garancija tužilačke autonomije u državama zapadnog Balkana, Anali Pravnog fakulteta u Beogradu, 2017, vol. 65, no. 1, pp. 169-186

31 Gutmann; Voigt, op. cit., note 10 
The judiciaries of the Member States called the CJEU to make decision in the specific cases and to provide interpretation whether there is a violation of the rule of law and judiciary independence.

The CJEU jurisprudence represents significant source of EU law. The CJEU decisions are important for the interpretation of the European Union law as well as for application of general EU law principles. Some of the CJEU decisions shaped development of EU legal system and influence on national legislation. Role of the CJEU in development of EU law is formed in the article 19(1) TEU, which envisages that Court "shall ensure that in the interpretation and application of the Treaties the law is observed". Although the national courts are deciding cases that relates to the application of the EU law, provisions of the Treaty establishing the European Community introduced competence of the CJEU to decide on questions referred by national courts of the members states that are related to the application of the EU acquis in specific case. ${ }^{32}$

Request for preliminary ruling, according to the article 267 of the TFEU, is referred by the national court of the member state to the CJEU, which has exclusive jurisdiction to interpret founding treaties, ${ }^{33}$ and interpret and decide on validity of EU acts. National court of the member state is entitled to requesting preliminary ruling when it has dilemma in interpretation or validity of an EU law. In this procedure the CJEU is not acting as appeal court that decide on facts at main hearing or interpretation and application of national law. ${ }^{34}$ Preliminary ruling procedure is treated as special phase of the procedure in front of the national courts of the members state. ${ }^{35}$ CJEU decision is final. Decision of the CJEU includes interpretation of the harmonization of national law with EU acquis and national court has obligation to apply CJEU interpretation in the national legal system. ${ }^{36}$

Preliminary ruling procedure is often described as the most important mechanism that enables constitutionalizing of EU legal system and development of EU law principles. ${ }^{37}$ Recent CJEU judgement in Case $L M$ underlines relevance of the Court interpretation in the rule of law area. This judgement is allowing national courts to assess the rule of law compliance of the Member States issuing the

\footnotetext{
32 Stanivuković, M., Pojedinac pred Sudom evropskih zajednica, Službeni glasnik, Beograd 2009, pp. 43.

33 Vukadinović, R., Pravo Evropske unije, Megatrend, Beograd 2001

34 Harlow, C., Three phases in the evolution of EU administrative law, in: Craig, P.; De Burca, G., (eds.), The Evolution of EU Law, Oxford University Press, 2011, pp. 442

35 M. Stanivuković, op. cit., note 32, pp. 44.

36 Harlow, C., op. cit., note 34, pp. 455.

37 de la Mare, T.; Donnelly, C., Preliminary Rulings and EU Legal Integration: Evolution and Stasis, in: P. Craig, G de Burca (eds.), The Evolution of EU Law, Oxford University Press, 2011, pp. 363-393
} 
European Arrest Warrant (EAW) within the concrete case and to postpone their cooperation with those countries that are compromising the rule of law. ${ }^{38}$

The rule of law backsliding allowed the national judiciaries to raise issues of Member States judicial standards to the CJEU. One of the main issues that was interpreted by the CJEU is independence of the judiciary as an EU law principle and element of the rule of law. ${ }^{39}$ As national courts are obliged to apply EU law they are considered as "arm of EU law" that allows functioning of the EU law system only if they are independent. ${ }^{40}$ These interpretations allowed the national courts under the treat to use the preliminary ruling procedure to safeguard own independence. ${ }^{41}$ Lately, many Polish courts submitted references concerning the Polish reforms restraining the judiciary and jeopardizing separation of powers.

One of the CJEU answers on the rule of law backsliding is the Court's decision in case C-64/16 Associação Sindical dos Juizes Portugueses $v$ Tribunal de Contas. ${ }^{42}$ The judgement establishes a general obligation for Member States to guarantee and respect the independence of their national courts and tribunals (par. 42). This obligation is established by interpretation of the Article 19(1) TEU and Article 2 and Article 4(3) TEU. The Court elaborated concept of independence of judiciary as autonomous exercise of judicial functions without hierarchical limitation or subordination to other body or obligation to follow instructions or orders from other institution, or external pressure that can jeopardize independence in decision making (par. 44).

In the same judgement the CJEU defined elements of the independence that need to be assessed in the process of deciding if some court or tribunal is independent. Legal foundation of the court or tribunal is one of the key factors, namely whether the body is established by law and if it is established permanently or ad hoc. Furthermore, it has to be analyzed if jurisdiction of the court or tribunal is compulsory and whether procedure is inter partes and if court applies the rule of law (par. 38).

38 Spieker, L. D., Breathing Life into the Union's Common Values: On the Judicial Application of the Article 2 TEU in the EU Value Crisis, German Law Journal, 2019, vol. 20, no. 8, pp. 1197

39 Krajewski, M., Associação Sindical dos Juizes Portugueses: The Court of Justice and Athena's Dilemma, European Papers, 2018, vol. 3, no, 1, pp. 395-407

40 Lenaerts, K., Upholding the Rule of Law through Judicial Dialogue, Yearbook of European Law, 2019, vol. 38, pp. 3-17

${ }^{41}$ Biernat, S.; Kawczyńska, M., Why the Polish Supreme Court's Reference on Judicial Independence to the ECJ is Admissible after all, 2018, [www.verfassungsblog.de/why-the-polish-supreme-courts-referenceon-judicial-independence-to-the-ECJ-is-admissible- after-all/], accessed 31. March 2020

42 Case C-64/16 Associação Sindicaldos Juizes Portuguesesv Tribunalde Contas [2018] ECLI:EU:C:2018:117 
Conditions under which the CJEU can provide interpretation of the national justice system organization are set in the Case Commission v Poland. ${ }^{43}$ The CJEU explained that although the organization of the national justice systems is an exclusive competence of the Member States, the Member States committed themselves to respecting and promoting common values referred to in Article 2 TEU (par. 42). The Court specifically mentioned rule of law as one of the common values that national courts would recognize (par. 43).

The CJEU confirmed its previous interpretation ${ }^{44}$ that national authorities must respect the principle of judicial independence even in situations where national judicial reforms do not implement EU law, since Article 19(1) TEU relates to any national court which may rule on questions concerning application or interpretation of EU and any national measure influencing on the independence of these courts falls within the jurisdiction of the EU law (par. 52).

The Commission v Poland case is relevant for incorporating principle of the irremovability of judges as one of the fundamental guarantees of the independence. The CJEU concluded that the forced early retirement is not in compliance with the principle of irremovability (par. 72) and standard that judges may remain in post until expiration of the mandate or reaching of the retirement age (par. 76). However, the Court did not provide any guideline how to achieve principle of irremovability nor indicated institutional measure, only included possibility that exception of the irremovability could be "warranted by legitimate and compelling grounds, subject to the principle of proportionality" (par. 76). Instead of providing general guideline applicable to any future situation, the Court decided in the specific case based on the assessment whether the national measures that lowered the retirement age for active judges could be justified and found that chosen measure was not suitable to improve age balance among senior members of the Supreme Court and standardize the general retirement age (par. 90). ${ }^{45}$

The CJEU in the same case assessed issues of external influences over the judiciary, specifically resistance of the court or tribunal to external factors and pressure that could damage independent judgement (par. 108). In the specific case the Court underlined that it is within the competences of the Member States to decide on the possibility of an extension of the mandate of judicial office holders beyond normal retirement age, however the conditions and procedures for extension should not undermine the principle of judicial independence (par. 110). Solution that was introduced in Poland that President of the Republic is entrusted with the

\footnotetext{
43 Case C-619/18 Commission v Poland [2019] ECLI:EU:C:2019:531

44 Position from the case C-64/16 Associação Sindical dos Juízes Portugueses

45 Sledzinska-Simon; Bard, op.cit., note 2, pp. 444
} 
power to decide whether to grant any extension of the judge's mandate beyond retirement age, while there were no substantive conditions and detailed procedural rules governing the adoption of such decisions cause a doubts on impartiality of the judges (par. 111).

The regulation of the disciplinary procedure against judiciary members is one of the crucial elements of the judicial independence and the CJEU confirmed that the Court's case law requires that the rules governing the disciplinary system and dismissal of judges "must provide the necessary guarantees in order to prevent any risk of that disciplinary regime being used as a system of political control of the content of judicial decisions" (par. 77). The Court concluded that to ensure independence of judiciary, rules on disciplinary procedure must include the right of the defence and possibility of bringing legal proceedings challenging the disciplinary bodies' decision (par. 77).

The CJEU in joined cases A.K. and Others v Krajowa Rada Sadownictwa ${ }^{46}$ have continued to assess rules governing judicial independence, including disciplinary system in Poland and the Polish National Council of Judiciary based on the request for preliminary ruling. More precisely the Court decided on independence of the Disciplinary Chamber of the Supreme Court of Poland. The Court avoided to clearly state whether the Disciplinary Chamber and National Council of Judiciary are bodies independent from the executive and legislative powers and left final decision to the referring court. However, the Court provided to referring court elements for assessment, including external and internal aspects of independence (par. 121,122). The Court highlighted that guarantees of independence and impartiality must include rules on the composition of the body and the appointment, length of service and grounds for abstention, rejection and dismissal of its members to ensure its neutrality (par. 123). Independence and impartiality rules should prevent both direct and indirect influence that can have effects on the decision of the judges (par. 125). The CJEU stated that it is very unlikely that the National Council of Judiciary and Disciplinary Chamber can past test of independence.

Shaping of the EU judicial standards will be continued in the request for the preliminary ruling in the Case Repubblika v Il Prim Ministry. ${ }^{47}$ The CJEU will need to address issues of judicial appointment, specifically system that exists in Malta and whether the role of the Prime Minister in the process jeopardizes independence.

\footnotetext{
46 Joined cases C-585/18, C-624/18 and C-625/18 A.K. and Others v Krajowa Rada Sadownictwa [2019] ECLI:EU:C:2019:982

47 Case C-896/19 Repubblika v Il Prim Ministry [2020] OJ C 77
} 
The further development of the jurisprudence will operationalize the rule of law standards in the EU.

The CJEU jurisprudence and standards on public prosecution mostly were developed through the preliminary rulings that were adopted in the context of the application of the European arrest warrant. ${ }^{48}$ These CJEU decisions are also relevant since they are contributing to interpretation of the term of judicial authority within the EU framework and broaden understanding to cover both judges and public prosecutors. According to the CJEU interpretation the judicial authority includes public prosecution as an "authority responsible for administering criminal justice in the national legal system” (par. 53, Openbaar Ministerie v Halil Ibrahim Özçelik). ${ }^{49}$

In deciding on the EAW application the Court examined whether the Member States public prosecution as authority that is issuing EAW has a sufficient level of judicial protection in issuing a warrant. The CJEU in its judgment form 27 May 2019 in the Case Minister for Justice and Equality $v$ OG and PI decided that public prosecution in Germany lacks guarantees of independence from executive and thus political interference and cannot issue European arrest warrant. ${ }^{50}$ The Court assessed independence of the German public prosecution based on statutory framework and an institutional framework and its capability to prevent external influences. Specifically, the Court examined whether the prosecution service in deciding on issuing of the arrest warrant is exposed to an instruction from the executive (par. 74). The Minister of Justice is part of the German prosecution hierarchical structure and has power to issue instruction to the prosecution authorities, which was considered by the CJEU as lack of independence.

However, the CJEU in the joined cases $J R$ and $Y C$ C-566/19 found that hierarchical subordination of the public prosecution to the Minister of Justice in France does not jeopardize independence, since the Minister cannot issue individual instructions to public prosecutors, except general instructions on criminal justice policy to ensure unified application throughout country. ${ }^{51}$ The CJEU in its jurisprudence is assessing only guarantees of prosecutors' independence from external influence, especially from executive branch, while internal hierarchy and internal

\footnotetext{
48 Council Framework Decision 2002/584/JHA on the European arrest warrant and the surrender procedures between Member States [2002] OJ L190

49 Case C-453/16 PPU Openbaar Ministerie v Halil Ibrahim Özçelik [2016] ECLI:EU:C:2016:860

50 Joined Cases C-508/18 and C-82/19 PPU Case Minister for Justice and Equality v OG and PI [2019] ECLI:EU:C:2019:456

51 Joined cases C-566/19 PPU and C-626/19 PPU JR and YC [2019] ECLI:EU:C:2019:1077, par. 54
} 
instructions coming from superior prosecutors is not perceived as prevention of independence (par. 56).

In the Case Minister for Justice and Equality v PF the CJEU found that Constitutional guarantees of independence of public prosecution in Lithuania and provisions on independence in the Law on the Public Prosecutor's Office of the Republic of Lithuania provides enough guaranties of independence from executive. ${ }^{52}$ The CJEU concluded that the prosecution service in Lithuania has sufficient guarantees of independence from executive to issue EAW.

The CJEU took formalistic approach in assessing prosecutorial independence and analysed only statutory and organizational rules. As it is already mentioned, the scope of the CJEU's assessment of the prosecutors' independence is limited to issuing of the EAW and not to the exercise of prosecutorial powers. This limited approach influence on narrow scope of the CJEU jurisprudence on public prosecution and standards. However, increased legislative activities in the area of judicial cooperation in criminal matters will lead to increase of requests for preliminary rulings that relates on public prosecution and thus development of the CJEU jurisprudence in this area.

Implications of the CJEU decisions could be twofold and could affect national normative framework, either through amendments of substantive or procedural legislation or through changing organization of judiciary. For example, as a response to the CJEU decision Germany did not change organization of prosecution service to remove role of minister of justice as potential external influence on prosecution but changed procedural rules and include courts in the process of issuing of the EAW. ${ }^{53}$

\section{HOW CJEU COULD INFLUENCE EU ACCESSION PROCESS AND REFORM OF JUDICIARY IN CANDIDATE COUNTRIES}

Over last three decades we could notice that candidate countries are facing challenges to introduce European standards in judiciary and once when they become members to ensure irreversibility of the process. Mechanisms of influence on organization of judiciary were more efficient in candidate countries through the negotiation procedure and monitoring of reform implementation.

EU enlargement is more than territorial increase. Enlargement incentivise creation of new politics, institutional organization of EU and influence on legal acts,

\footnotetext{
52 Case C-509/18 Minister for Justice and Equality v PF [2019] ECLI:EU:C:2019:457, par. 55

53 Working paper, Council of European Union, WK 6666/2019 INIT, 28 May 2019
} 
both in EU member states and candidate countries. ${ }^{54}$ Implementation of the EU acquis in rule of law area is requirement of accession negotiation and got central role during 2004, 2007 and 2013 enlargement, while judicial cooperation in civil and criminal matters is one of the requirements. Characteristic of EU accession process is strong role of the EU that transposes EU acquis to third countries. ${ }^{55}$ States that aspire to become EU members states are in obligation to adopt and implement EU acquis. Conditionality is methodology that is applied during accession process to ensure that new member states can absorb requirements incorporated in the EU acquis and implement obligations from the membership. ${ }^{56}$

During the EU enlargement to the East, the EU faced with the situation that countries in the transition, with different economic, political and social environment, are aspiring to become members. To address this challenge, the EU develop approach that was wider that simple requirement to harmonize national legislation with EU acquis. ${ }^{57}$ European Council adopted in 1993 the Copenhagen criteria that included, among other requirement, stability of institutions guaranteeing democracy, rule of law, human rights and respect for and protection of minority rights, and functioning market economy and the ability to cope with competitive pressure and market forces within the EU. Copenhagen criteria were gradually developed and extended. As a result, European Council organized 1995 in Madrid adopted conclusions where is stated that it is not sufficient condition to have political commitment of the candidate countries to adopted EU acquis, but they have to adjust administrative structures to guarantee efficient application of the EU acquis. When it comes to the rule of law, the EU policy developed over time. Countries that intends to join to the EU during negotiation process have to make sure that their judiciary is independent and impartial, which includes guaranteed access to justice, fair trial procedures, adequate funding for courts and training for magistrates and legal practitioners, while laws are clear, publicised, stabile, fair and protect human rights. In addition, candidate country government and its officials need to be accountable under the law and take a clear attitude against corruption.

54 Hillion, C., EU Enlargement, in: Craig, P., De Burca, G., (eds.), The Evolution of EU Law, Oxford, 2011, pp. 187-217

55 Cremona, M., The Union as a Global Actor: Roles, Models and Identity, Common Market Law Review, 2004, vol. 41, no. 2, pp. 555-573

56 Smith, K. E., Evolution and Application of the EU Membership Conditionality, in: Cremona, M. (ed.), The Enlargement of the European Union, Oxford University Press, Oxford 2003, pp.105-140

57 Matic Boskovic, M., Obaveza uskladivanja sa pravnim tekovinama Evropske unije, in: Škulic, 囚.; Ilic, G.; Matic Boskovic, M., (eds.), Unapređenje Zakonika o krivičnom postupku: de lege ferenda predlozi, Beograd, Udruženje javnih tužilaca i zamenika javnih tužilaca, 2015, pp. 149-158 
During '90s of the XX century the EU adopted significant number of EU acquis in the area of criminal law and judiciary. After terrorist attack from 11 September $2001 \mathrm{EU}$ put criminal matters and judicial cooperation in this area as a priority, including application of mutual recognition and mutual trust among member states. ${ }^{58}$ However, shortcomings that existed in states that joined EU in 2004, influenced on the decision that new member states cannot automatically join to Schengen system. Intergovernmental mechanism was used for decision on full membership status to the Schengen system, which requires unanimously decision of all member states that new members fulfil membership conditions. ${ }^{59}$ The article 39 of the Act on accession contained protection clause to include potential shortcomings in the application of the EU instruments in the area of mutual recognition in criminal matters in the new member states. The protection clause envisaged possibility for the Commission to temporary suspend provisions on judicial cooperation in criminal matters in case of shortcomings or risk. Period of validity of protection clause was three years and it has never been used.

When Bulgaria and Romania became member states, progress in the area of judiciary and internal affairs were closely followed and monitored. ${ }^{60}$ European Commission Progress reports emphasized shortcomings of the progress in the area of judiciary and internal affairs, including lack of institutional capacities. The European Commission even questioned if countries would become members in 2007 as it was planned. ${ }^{61}$ To enable that these states become members in the planned timeframe, European Commission introduced Cooperation and verification mechanism (CVM) as additional security mechanism in both countries. ${ }^{62}$ Benchmarks of the CVM requires changes in the organization of judiciary. Romania were obliged to ensure transparent and efficient court procedure, while Bulgaria needed to ensure guarantees of independence of judiciary through constitutional

$58 \quad$ Mitsilegas, V., EU Criminal Law, Hart Publishing, 1 ${ }^{\text {st }}$ Edition, 2009. pp. 284

59 Monar, J., Enlargement-Related Diversity in EU Justice and Home Affairs: Challenges, Dimension and Management Instruments, Dutch Scientific Council for Government Policy, Working Document W 112, The Hague 2000, [https://english.wrr.nl/publications/publications/2000/12/18/enlargement-related-diversity-in-eu-justice-and-home-affairs-challenges-dimensions-and-management-instruments], accessed 30. March 2020

${ }^{60}$ Bozhilova, D., Measuring Success and Failure of EU: Europeanization in the Eastern Enlargement: Judicial Reform in Bulgaria, European Journal of Law Reform, vol. 9, 2007, pp. 285-319

${ }^{61}$ European Commission, Monitoring report on the state of preparedness for EU membership of Bulgaria and Romania, COM (2006) 549 final, Brussels, 26 September 2006

62 Commission Decision 2006/929/EC establishing a mechanism for cooperation and verification of progress in Bulgaria to address specific benchmarks in the areas of judicial reform and the fight against corruption and organised crime [2006] OJ L 354; Commission Decision 2006/928/EC establishing a mechanism for cooperation and verification of progress in Romania to address specific benchmarks in the areas of judicial reform and the fight against corruption [2006] OJ L 354 
amendments and removal of ambiguity in relation to independence and accountability of judiciary system. ${ }^{63}$

Experience with Bulgaria and Romania in which significant shortcomings remain after accession to the EU, influenced on the Commission to revise approach and introduce practice that negotiation on Chapters 23 and $24^{64}$ are open the first and close at the end of the negotiation process. This approach was used for the first time with Croatia that became EU member state in 2013. The same practice was applied with Montenegro that opened accession negotiation in 2012 and Serbia that opened in 2014.

The EU influence on organization of judiciary in candidate countries, could be identified through the recommendations included in the Screening reports for Chapters 23 and $24^{65}$ and the Action plans for these chapters. ${ }^{66}$ In the Screening report EU experts assessed the area of judiciary through three dimensions: independence of judiciary; impartiality and accountability; and professionalism, competence and efficiency. For each of dimensions the Screening report provides overview of legislative and institutional framework and compare it with the European standards. The Screening report contains recommendations to take additional activities to ensure complete independence of judiciary, impartiality and better efficiency. European Commission biannually assess progress of implemented reforms:

Although Serbian authorities accepted recommendations from the Screening report for Chapter 23 and incorporated measures in the Action plan for Chapter 23 only moderate progress was achieved for four years since its adoption. ${ }^{67}$ Draft amendments of the Constitution instead of introduction of stronger guarantees of

63 Trauner, F., Post-accession compliance with EU law in Bulgaria and Romania - a comparative perspective, European Integration online Papers (EIoP), vol. 13, no. 2, article 21, 2009, [http://eiop.or.at/eiop/ texte/2009-021a.htm], accessed 07. April 2020

64 Chapter 23 relates to judiciary and fundamental rights. European standards in the Chapter 23 include strengthening independence, impartiality and professionalism in judiciary, enforcement of measures of prevention and fight against corruption and maintenance of high standards of protection of human and minority rights. Chapter 24 relates to justice, freedom and security. European standards include 11 areas thematic areas: external borders and Schengen system of migration, asylum, visa, police cooperation, fight against organize crime, fight against human trafficking, fight against terrorism, fight against drug, judicial cooperation in civil and criminal matters and custom cooperation

${ }^{6}$ Vodič kroz Izveštaj o skriningu za poglavlje 23 - pravosude i osnovna prava, Beogradski centar za bezbednosnu politiku i Beogradski centar za ljudska prava, Beograd, 2015

66 Action plan for Chapter 23 is available at: [https://www.mpravde.gov.rs/tekst/9849/finalna-verzija-akcionog-plana-za-pregovaranje-poglavlja-23-koja-je-usaglasena-sa-poslednjim-preporukama-i-potvrdjena-od-strane-evropske-komisije-u-briselu-.php], accessed 07. April 2020

67 Serbia 2019 Report, 2019 Communication on EU Enlargement Policy, COM(2019) 260 final, 29.05.2019, "It made some progress during the reporting period: while last year's recommendations have only been partially addressed...", pp. 13 
independence of judiciary open possibilities for greater external control over judiciary ${ }^{68}$ Proposed draft amendments on composition of Councils raised debate if there are common European standards on this issue, as well as on the appointment of judges and prosecutors and role of ministry of justice in administration and management of judiciary. These discussions and adopted opinions of the Consultative Council of European Judges, Consultative Council of European Prosecutors and Venice Commission confirmed need for existence on the EU level clear guidelines on reform of judiciary and standards for ensuring independence, impartiality and accountability of judiciary.

The CJEU decisions provided arguments for the Consultative Council of European Prosecutors and Consultative Council of European Judges to request in their opinions higher standards in protection of independence of judiciary and prosecution service in Serbia. Elaboration of standards on judiciary by the CJEU also enables their better understanding in specific national context. Thus, European Commission as a leading institution in the negotiation process could use reasoning from the CJEU judgments in assessing progress in the justice reforms of candidate countries.

Reversibility of justice reforms in some Member States and slow reforms in candidate countries led to adoption of the EU revised enlargement methodology from February 2020 that is putting an even stronger focus on the core role of fundamental reforms essential for the EU path. Within this methodology the rule of law will become even more central in the accession negotiations, while progress on the fundamental reforms will determine the overall pace of negotiations. ${ }^{69}$ It has to be seen how this revised enlargement methodology will be applied in the practice. Although the negotiation procedure has become stricter over the time, existing mechanisms were not sufficient to track real progress in the justice reforms. Most of the activities were focus on amending legislation, while independence and ac-

68 Consultative Council of European Prosecutors, Opinion of the CCPE Bureau following a request by the Prosecutors Association of Serbia to assess the compatibility with European standards of the proposed amendments to the Constitution of Serbia which will affect the composition of the High Prosecutorial Council and the way prosecutors work, 27 March 2019 and 25 June 2018; Consultative Council of European Judges, Opinion of the CCJE Bureau following request by the Judges' Association of Serbia to assess the compatibility with European standards of the proposed amendments to the Constitution of Serbia which will affect organization of judicial power, 4 May 2018 and 21 December 2018

69 Communication from the Commission to the European Parliament, the Council, the European Economic and Social Committee and the Committee of the Regions, Enhancing the accession process - A credible EU perspective for the Western Balkans, Brussels, 5.2.2020, COM(2020) 57 final, [https:// ec.europa.eu/neighbourhood-enlargement/sites/near/files/enlargement-methodology_en.pdf], accessed 07. April 2020 
countability of judiciary remain the problems in all candidate countries. Additional challenge for the EU and its institutions are countries that are members for more than decade, which are over the last few years facing with reversible processes and violation of rule of law. The backsliding of rule of law in the member states is jeopardizing mechanisms of mutual trust and mutual recognition and put in the risk judicial cooperation and functioning of are of freedom, security and justice.

\section{CONCLUSION}

Backsliding of the rule of law in EU member states, as well as challenges with the enlargement process in Western Balkan countries confirm needs for setting hard European standards on independence of judiciary and mechanism for monitoring its application in the practice. The EU Commission has significant role, but during recent years the CJEU is shaping judicial standards that should ensure mutual trust and mutual recognition in the judicial cooperation among EU Member States.

Although there are many concerns if CJEU jurisprudence is unified, ${ }^{70}$ its judgements are of utmost importance for national judiciaries and for protection of individual rights. Either in the process of preventing backsliding of rule of law or as a guide in justice reforms for candidate countries the CJEU jurisprudence enables better understanding of the content of rule of law as a common value. The CJEU jurisprudence already included process for appointing judges and irremovability of judges as one of the elements of judicial independence. The Court also stated that rules must ensure the exclusion of any doubt that independence and impartiality are jeopardize by external factors or interests.

Having in mind differences in organization of judiciaries it is not realistic to expect that the CJEU could provide specific recommendations and tailor-made standards that are directly applicable in member states or candidate countries. However, the CJEU and the EU institutions need to remain attentive with regards to modifications of judicial organizations and amendments of rules that put at risks protection of individual rights and application of EU law.

70 Jacobs, M.; Muender, M.; Richter, B., Subject Matter Specialization of European Union Jurisdiction in the Preliminary Rulings Procedure, German Law Journal, vol. 20, no. 8, 2019, pp. 1214-1231 


\section{REFERENCES}

\section{BOOKS AND ARTICLES}

1. Autheman, V., Sandra Elena, S., Global best practices: Judicial Council-Lessons learned from Europe and Latin America, USAID, 2004

2. Bozhilova, D., Measuring Success and Failure of EU: Europeanization in the Eastern Enlargement: Judicial Reform in Bulgaria, European Journal of Law Reform, vol. 9, 2007, pp. 285319

3. Bugarič, B., Central Europe's descent into autocracy: A constitutional analysis of authoritarian populism, International Journal of Constitutional Law, vol.17, no. 2, 2019, pp. 597-616

4. Craig, P., The Lisbon Treaty - Law, Politics, and Treaty Reform, Oxford University Press 2013

5. Cremona, M., The Union as a Global Actor: Roles, Models and Identity, Common Market Law Review, 2004, vol. 41, no. 2, pp. 555-573

6. Defeis, E. F., Human Rights and the European Court of Justice: An Appraisal, Fordham International Law Journal, vol. 31, no. 5, 2007, pp. 1104-1117

7. de la Mare, T.; Donnelly, C., Preliminary Rulings and EU Legal Integration: Evolution and Stasis, in: P. Craig, G de Burca (eds.), The Evolution of EU Law, Oxford University Press, 2011, 363-393

8. Garoupa, N.; Ginsburg, T., Guarding the Guardians: Judicial Councils and Judicial Independence, American Journal of Comparative Law, vol. 57, Oxford University Press 2008, pp. $103-134$

9. Guarneri, C., Judicial independence in Europe: threat or resource for democracy?, Representation, Journal of Representative Democracy, 2013, vol. 49, no. 3, pp. 347-359

10. Harlow, C., Three phases in the evolution of EU administrative law, in: Craig, P.; De Burca, G., (eds.), The Evolution of EU Law, Oxford University Press 2011, pp. 439-464

11. Hillion, C., EU Enlargement, in: Craig, P., De Burca, G., (eds.), The Evolution of EU Law, Oxford, 2011, pp. 187-217

12. Jacobs, M.; Muender, M.; Richter, B., Subject Matter Specialization of European Union Jurisdiction in the Preliminary Rulings Procedure, German Law Journal, 2019, vol. 20, no. 8, pp. 1214-1231

13. Krajewski, M., Associação Sindical dos Juizes Portugueses: The Court of Justice and Athena's Dilemma, European Papers, 2018, vol.3, no. 1, pp. 395-407

14. Lenaerts, K., Upholding the Rule of Law through Judicial Dialogue, Yearbook of European Law, 2019, vol. 38, pp. 3-17

15. Lenaerts, K., New Horizons for the Rule of Law Within the EU, German Law Journal, 2020, vol. 21, no. 1, pp. 29-34

16. Matić Bošković, M., Tužilački saveti i garancija tužilačke autonomije u državama zapadnog Balkana, Anali Pravnog fakulteta u Beogradu, 2017, vol. 65, no 1, pp. 169-186

17. Matic Boskovic, M., Obaveza uskladivanja sa pravnim tekovinama Evropske unije, in: Škulic, M.; Ilic, G.; Matic Boskovic, M., (eds.), Unapređenje Zakonika o krivičnom postupku: de lege ferenda predlozi, Beograd, Udruženje javnih tužilaca i zamenika javnih tužilaca, 2015, pp. $149-158$ 
18. Matić Bošković, M.; Ilić, G., Javno tužilaštvo u Srbiji: Istorijski razvoj, medunarodni standardi, uporedni modeli i izazovi modernog društva, Institut za kriminološka i sociološka istraživanja, Beograd, 2019

19. Matić Bošković, M.; Nenadić, S., Evropski standardi u oblasti pravosuda, Strani pravni život, 2018, vol. 62, no 1, pp. 39-56

20. Mitsilegas, V., EU Criminal Law, Hart Publishing, $1^{\text {st }}$ Edition, 2009

21. Peers, S., Justice and Home Affairs Law since the Treaty of Lisbon: A Fairy-Tale Ending?, in: Arcarazo, D. A.; Murphy, C. C. (eds.), EU Security and Justice Law after Lisbon and Stockholm, Hart Publishing, 2014, pp. 17-37

22. Pech, L.; Scheppele, K.L., Illiberalism Within: Rule of Law Backsliding in the EU, Cambridge Yearbook of European Legal Studies, 2017, vol. 19, pp. 3-47

23. Sledzinska-Simon, A.; Bard, P., The Teleos and the Anatomy of the Rule of Law in EU Infringement Procedures, Hague Journal on the Rule of Law, 2019, vol. 11, no. 2-3, pp. 439-445

24. Smith, K. E., Evolution and Application of the EU Membership Conditionality, in: Cremona, M. (ed.), The Enlargement of the European Union, Oxford University Press, Oxford 2003, pp. $105-140$

25. Spieker, L. D., Breathing Life into the Union's Common Values: On the Judicial Application of the Article 2 TEU in the EU Value Crisis, German Law Journal, 2019, vol. 20, no. 8, pp. 1182-1213

26. Stanivuković, M., Pojedinac pred Sudom evropskih zajednica, Službeni glasnik, Beograd 2009

27. Škulić, M., Osnovni evropski standardi u krivičnom postupku Srbije, in: Kron, L.; Jugović, A., (eds.), Kriminal, državna reakcija i harmonizacija sa evropskim standardima, Institut za kriminološka i sociološka istraživanja, Beograd, 2013, pp. 29-55;

28. Tonry, M., Prosecutors and Politics in Comparative Perspective, Crime and Justice vol. 41, 2012, pp. 1-33

29. Vervaele, J. A. E., Evropsko kazneno pravo i opća načela prava Unije, Hrvatski ljetopis za kazneno pravo i praksu, vol. 12, no. 2, Zagreb 2005, pp. 855-882

30. Vukadinović, R., Pravo Evropske unije, Megatrend, Beograd 2001

\section{COURT OF JUSTICE OF THE EUROPEAN UNION}

1. Case C-216/18 PPU LM [2018] ECLI:EU:C:2018:586

2. Case C-64/16 Associação Sindical dos Juizes Portugueses v Tribunal de Contas [2018] ECLI:EU:C:2018:117

3. Case C-619/18 Commission v Poland [2019] ECLI:EU:C:2019:531

4. Joined cases C-585/18, C-624/18 and C-625/18 A.K. and Others v Krajowa Rada Sadownictwa [2019] ECLI:EU:C:2019:982

5. Case C-453/16 PPU Openbaar Ministerie $v$ Halil Ibrahim Özçelik [2016] ECLI:EU:C:2016:860

6. Joined Cases C-508/18 and C-82/19 PPU Case Minister for Justice and Equality v OG and PI [2019] ECLI:EU:C:2019:456

7. Joined cases C-566/19 PPU and C-626/19 PPU JR and YC [2019] ECLI:EU:C:2019:1077 
8. Case C-509/18 Minister for Justice and Equality v PF [2019] ECLI:EU:C:2019:457

\section{EU LAW}

1. Treaty of Lisbon amending the Treaty on European Union and the Treaty establishing the European Community [2007] OJ C306/01

2. Council Framework Decision 2002/584/JHA on the European arrest warrant and the surrender procedures between Member States [2002] OJ L190

\section{EUROPEAN COMMISSION DOCUMENTS}

1. European Commission, Monitoring report on the state of preparedness for EU membership of Bulgaria and Romania, COM (2006) 549 final

2. Commission Decision 2006/929/EC establishing a mechanism for cooperation and verification of progress in Bulgaria to address specific benchmarks in the areas of judicial reform and the fight against corruption and organised crime [2006] OJ L 354

3. Commission Decision 2006/928/EC establishing a mechanism for cooperation and verification of progress in Romania to address specific benchmarks in the areas of judicial reform and the fight against corruption [2006] OJ L 354

4. European Commission, Communication: A New EU Framework to Strengthen the Rule of Law, COM(2014) 158 final

5. Communication from the Commission to the European Parliament, the Council, the European Economic and Social Committee and the Committee of the Regions, Enhancing the accession process - A credible EU perspective for the Western Balkans, Brussels, 5.2.2020, $\operatorname{COM}(2020) 57$ final

6. Serbia 2019 Report, 2019 Communication on EU Enlargement Policy, COM(2019) 260 final

\section{UN DOCUMENTS}

1. Bangalore principles of judicial conduct, 2002

2. Report of the Special Rapporteur on the independence of judges and lawyers - Judicial accountability, 2014, A/HRC/26/32

3. Report of the Special Rapporteur on the independence of judges and lawyers, 18 April 2011, A/HRC/17/30/Add.3, paras. 16 and 87

\section{OSCE DOCUMENTS}

1. Document of the Copenhagen meeting of the conference on the human dimension of the OSCE from 1990

2. Document of the Moscow meeting of the conference on the human dimension of the OSCE from 1991 


\section{COUNCIL OF EUROPE DOCUMENTS}

1. European Charter on the statute for judges and Explanatory Memorandum, Council of Europe, 1998

2. Recommendation CM/Rec (2010)12 of the Committee of Ministers to member states on judges: independence, efficiency and responsibilities

3. Consultative Council of European Judges Opinion No 10 on Council for the Judiciary in the Service for Society, 2007

4. Consultative Council of European Prosecutors, Opinion of the CCPE Bureau following a request by the Prosecutors Association of Serbia to assess the compatibility with European standards of the proposed amendments to the Constitution of Serbia which will affect the composition of the High Prosecutorial Council and the way prosecutors work, 25 June 2018 and 27 March 2019

5. Consultative Council of European Judges, Opinion of the CCJE Bureau following request by the Judges' Association of Serbia to assess the compatibility with European standards of the proposed amendments to the Constitution of Serbia which will affect organization of judicial power, 4 May 2018 and 21 December 2018

\section{WEBSITE REFERENCES}

1. Bard, P., EU responses to rule of law backsliding in the Member States - the Hungarian case, 2017, Hungarian Europe Society, Budapest, available at: [https:/europatarsasag.hu/sites/ default/files/open-space/documents/magyarorszagi-europa-tarsasag-rolmet.pdf], accessed 31. March 2020

2. Biernat, S.; Kawczyńska, M., Why the Polish Supreme Court's Reference on Judicial Independence to the ECJ is Admissible after all, 2018, [www.verfassungsblog.de/why-the-polish-supreme-courts-reference-on-judicial-independence-to-the-ECJ-is-admissible- after-all/], accessed 31. March 2020

3. Gutmann, J.; Voigt, S., Judicial Independence in the EU - A Puzzle, ILE Working Paper Series, no. 4, 2017, [https:/www.econstor.eu/bitstream/10419/156756/1/ile-wp-2017-4. pdf], accessed 08. April 2020

4. Monar, J., Enlargement-Related Diversity in EU Justice and Home Affairs: Challenges, Dimension and Management Instruments, Dutch Scientific Council for Government Policy, Working Document W 112, The Hague 2000, [https://english.wrr.nl/publications/publications/2000/12/18/enlargement-related-diversity-in-eu-justice-and-home-affairs-challenges-dimensions-and-management-instruments], accessed 30. March 2020

5. Trauner, F., Post-accession compliance with EU law in Bulgaria and Romania - a comparative perspective, European Integration online Papers (EIoP), vol. 13, no. 2, article 21, 2009. [http://eiop.or.at/eiop/texte/2009-021a.htm], accessed 07. April 2020 